\title{
Design and Construction of a Tailings Dam over an Ancient Tailings Facility at La Parrilla Mine
}

\author{
José Miguel Galera² · Fernando de la Fuente ${ }^{1}$ Juan García ${ }^{1} \cdot$ Manuel Calleja $^{2} \cdot$ Vanesa Pozo $^{2}$
}

Received: 18 March 2020 / Accepted: 18 January 2021

(c) The Author(s) 2021, corrected publication 2021

\begin{abstract}
La Parrilla is a tungsten and tin mine located in western Spain. The tailings facility has a total capacity for $3 \mathrm{Mm}^{3}$ and will be executed in four different phases. The main constraint for the design and construction of the tailings dam is that it has been constructed over an existing one from the 1980s. The construction activities involved removal and substitution of the old tailings from the southern portion of the facility, ground improvement with gravel columns over an area of about $10,000 \mathrm{~m}^{2}$, and construction of the dyke's dam. This article describes the main design and construction aspects, including monitoring, until the dam's completion in June 2019.
\end{abstract}

Keywords Geotechnical stability · Gravel columns

\section{Introduction}

La Parrilla is a tungsten and tin mine located in the Extremadura region of western Spain, on the border of the provinces of Cáceres and Badajoz, about $310 \mathrm{~km}$ southwest of Madrid and $240 \mathrm{~km}$ north of Seville. The nearest towns are Merida at $50 \mathrm{~km}$ and Miajadas at $15 \mathrm{~km}$. Figure 1 shows the location of the mine.

La Parrilla mine operated underground from 1951 to 1968, and as an open pit between 1968 and 1986, when it was definitively closed. The current project has an Australasian Joint Ore Reserves Committee (JORC) compliant resources total of $49 \mathrm{Mt}$ at a grade of $998 \mathrm{ppm} \mathrm{WO}_{3}$, and

José Miguel Galera

jmgalera@subterra-ing.com

https://info@subterra-ing.com

Fernando de la Fuente

fdelafuente@wresources.com

Juan García

jgvalledor@wresources.com

Manuel Calleja

https://info@ subterra-ing.com

Vanesa Pozo

https://info@subterra-ing.com

1 W Resources, La Parrilla Mine, 10132 Almoharín, Cáceres, Spain

2 Subterra Ingeniería, Vallehermoso 18, 28015 Madrid, Spain
JORC compliant reserves of $29.8 \mathrm{Mt}$ at a diluted grade of $931 \mathrm{ppm} \mathrm{WO}_{3}$. The ore (containing scheelite and cassiterite) is initially fed to a crushing and screening plant. It is then pre-classified in a jig plant, from which it goes to a gravity concentration plant with spirals and shaking tables, and to a final phase of sulphide flotation and magnetic and electrostatic separation. The facility can process $2 \mathrm{Mt} / \mathrm{y}$ of ore and will produce $\approx 2.700 \mathrm{t}$ of tungsten concentrate and $500 \mathrm{t}$ of tin concentrate per annum.

Construction of the plants started in early 2018 and test production started in November 2019. The ramp-up phase to reach the nominal feed capacity of $2 \mathrm{Mt} / \mathrm{y}$ of ore took place during the first half of 2020 .

\section{Geology and Metallogeny of La Parrilla}

La Parrilla Mine is located in the southeastern part of the central Iberian zone of the Iberian Massif, also known as the Hercynian Massif, which occupies the western part of the Iberian Peninsula, composed of crystalline and metamorphic rocks from the Paleozoic. The mineralization comprises coarse-grained scheelite-bearing veins located within greywackes and slates of the "Complejo Esquisto-Grauváquico" formation, from the Precambrian-Lower Cambrian.

These rocks have been folded and fractured by the Cadomian, Hercynian (the most important), and Alpine orogenies, and have also been affected by a low-grade regional 


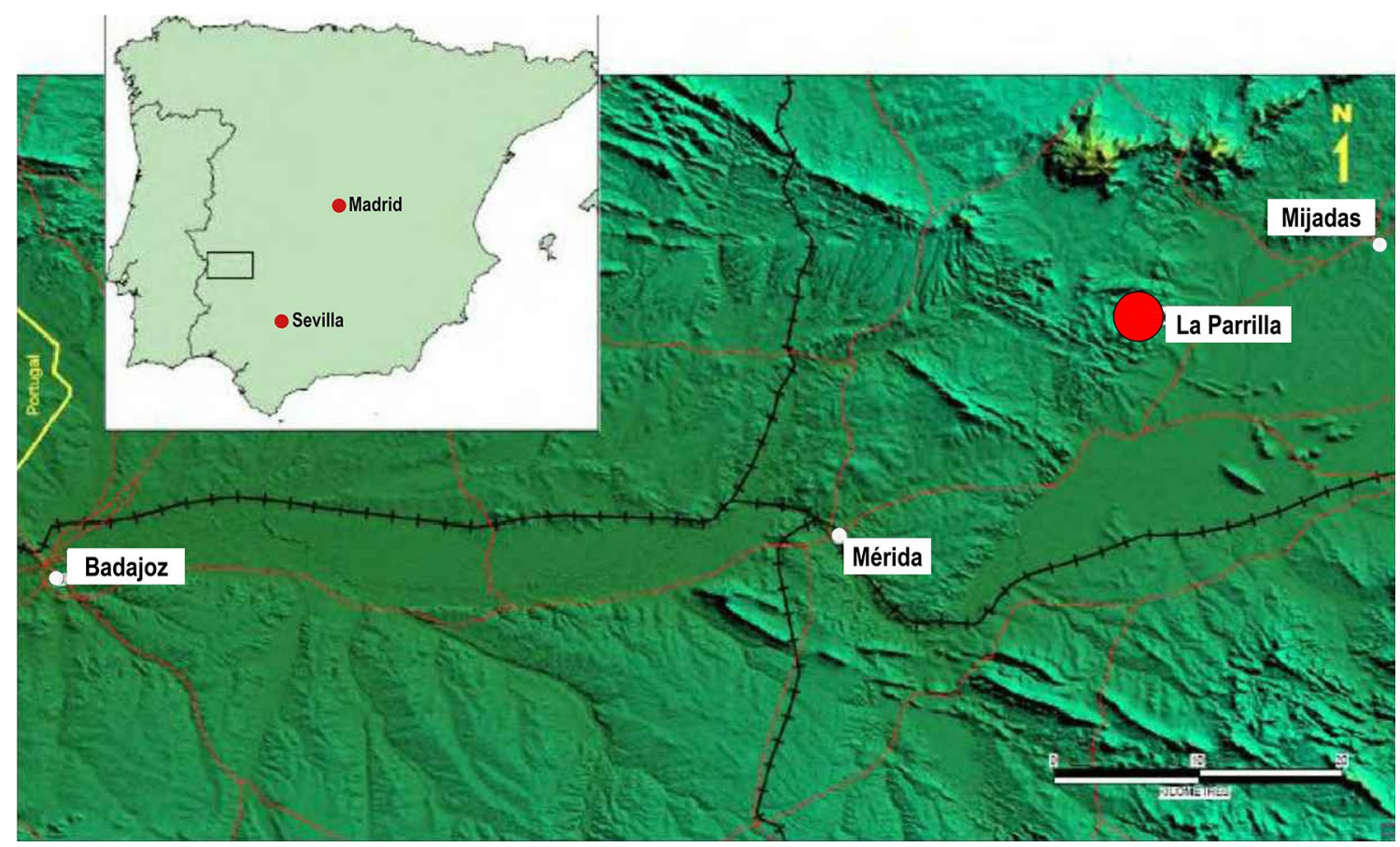

Fig. 1 Location of La Parrilla Mine

metamorphism (green shale facies). The existence of a contact metamorphism halo indicates the possible presence of a Hercynian granite batholite at depth. The geology and metallogeny of the mine have been studied in detail by Campos et al. (1995) and Gumiel and Campos (2002). Figure 2 shows a detail of the local geology of the mine site.

The genetic model for the mineralization of La Parrilla has been interpreted by several studies as having granitic affiliation. The mineralization is presented as beams of seams from within a ring-dyke model, disseminated in granitic fingers. The mineralised veins have a NE-SW orientation and dip $30^{\circ} \mathrm{SE}$, and their thickness range up to $3.95 \mathrm{~m}$. The veins show good continuity, over $300 \mathrm{~m}$ in depth and spanning several hundred meters. Mineralization consists of scheelite, arsenopyrite, cassiterite, and in less abundance, pyrite, sphalerite, muscovite, tourmaline, and wolframite. Figure 3 show the mineralization, while Fig. 4 illustrates the different veins.

\section{Description of the Tailings Dam}

The tailings facility is located downgradient of the pit and has a total capacity for $3 \mathrm{Mm}^{3}$, and is being constructed in four phases:

- Phase 1 (2018-2021) for 500,000 $\mathrm{m}^{3}$ of tailings, up to $+302 \mathrm{~m}$ above sea level (asl) has already been constructed and will ensure the tailings capacity needed for the first 2 years of exploitation. It occupies the NE corner of the facility and is located above an existing tailings facility from the 1980s. This circumstance has conditioned the dam's design as it has been necessary to replace the existing tailings and/or to improve the foundation with stone columns.

- Phase 2 (2021-2024) up to + $305.5 \mathrm{~m}$ asl will be constructed during the next 4 years of operation (20212024); the total volume of treatment tailings to be discharged into the facility in this second phase is 611,000 $\mathrm{m}^{3}$. The maximum height of the dam in this phase is $+305.5 \mathrm{~m}$ asl; the sludge fill will reach $+304.5 \mathrm{~m}$ asl, with a safeguard of $1 \mathrm{~m}$.

- Phase 3 (2024-2029) up to $309 \mathrm{~m}$ asl, will be constructed during the next 6 years of operation (2024-2029); the total volume of treatment tailings to be discharged into the facility in this second phase is $1,004,000 \mathrm{~m}^{3}$. The maximum height of the dam in this phase is $+309.0 \mathrm{~m}$ asl and the sludge filling will reach $+308 \mathrm{~m}$ asl, with a safeguard of $1 \mathrm{~m}$.

- Phase 4 (2029) up to $315 \mathrm{~m}$ asl, will be executed during the last eight years of operation (2030-2037); the total volume of treatment tailings to be discharged into the facility is $1,715,000 \mathrm{~m}^{3}$. The maximum height of the dam in this phase will be $+315.0 \mathrm{~m}$ asl and the sludge filling will reach $+314 \mathrm{~m}$ asl, with a safeguard of $1 \mathrm{~m}$.

Figure 5 shows a general plan of the facility with the proposed new design, where it can be seen that two types 


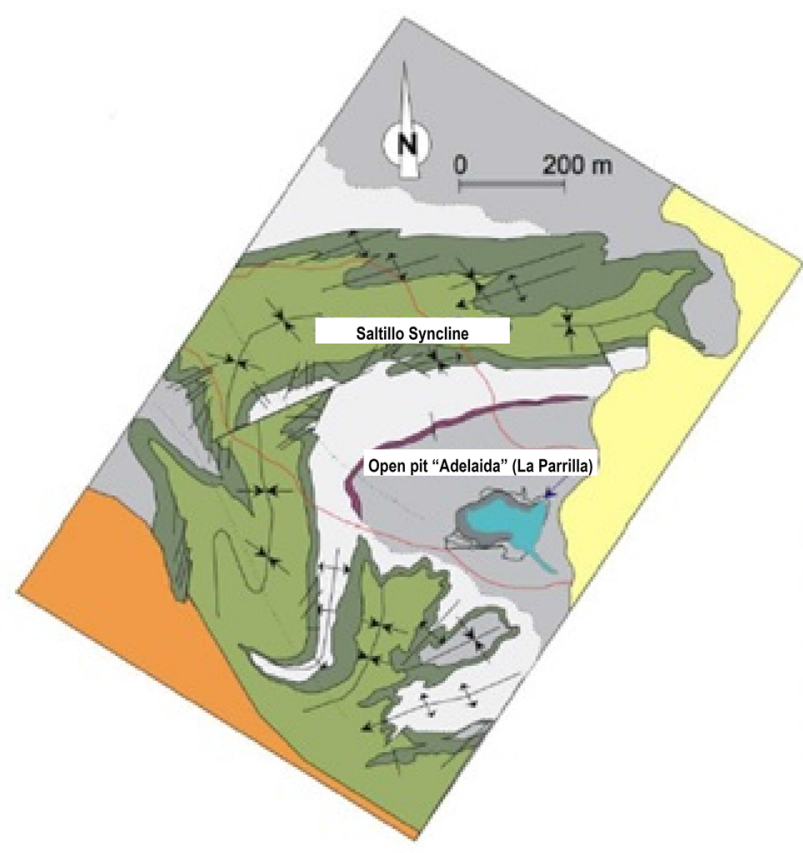

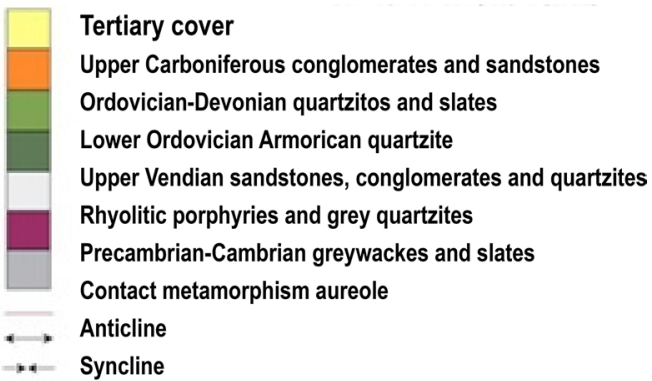

Fig. 2 Location of the Complejo Esquisto-Grauváquico formation, from the Precambrian-Lower Cambrian (Gumiel and Campos 2002)

Fig. 3 Genetic model for the mineralization of La Parrilla (Gumiel and Campos 2002)
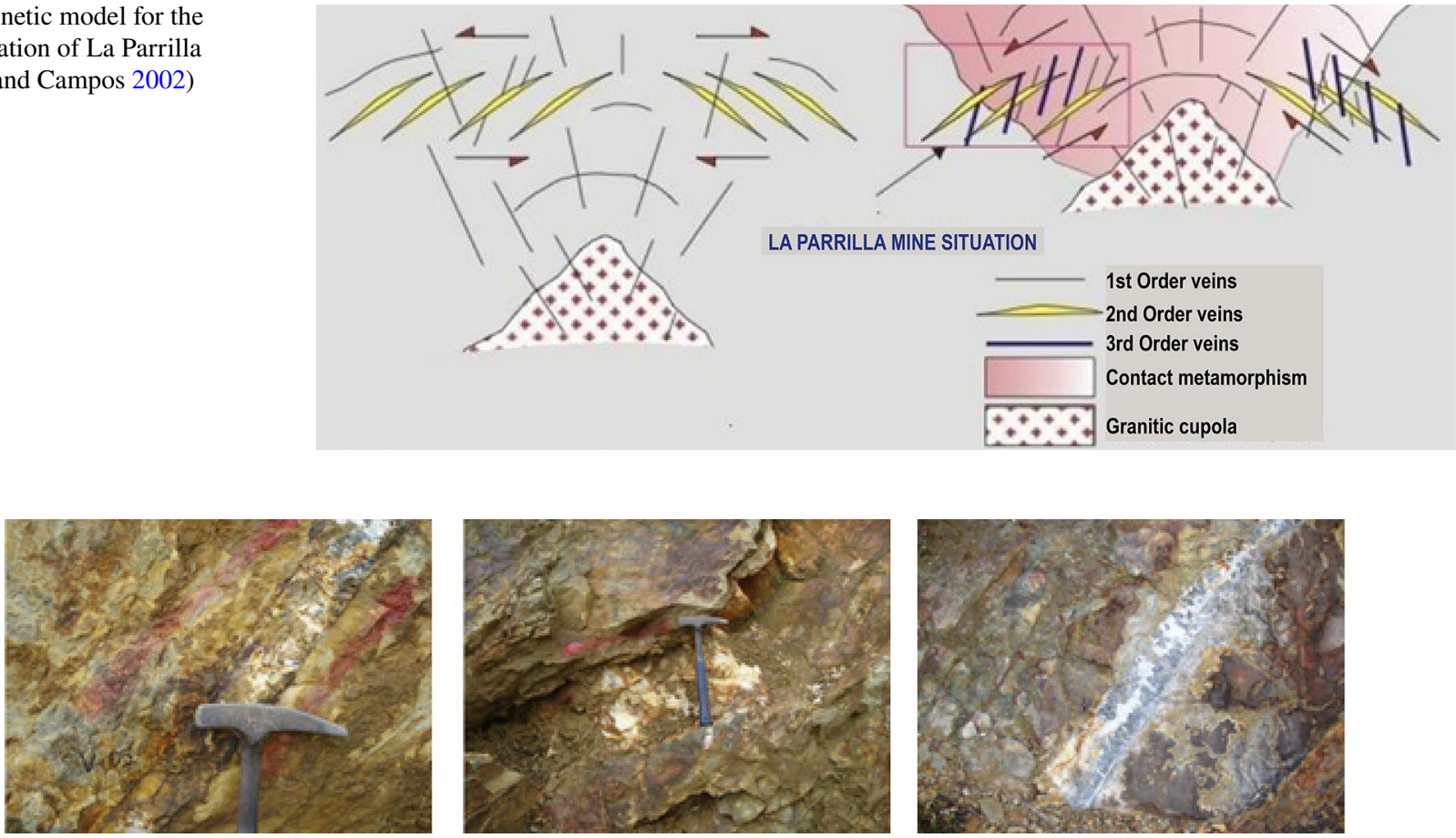

Fig. 4 Example of mineralised veins

of construction methodologies will be applied to the perimeter. Wherever a dyke is needed, a "downstream" type will be used while in the west and southern areas, the tailings will be confined by a slope excavated over an old dump that needs to be removed. The first and second phases of the facility will require special preparation, since the foundations for the new containment dykes are located on top of the old tailings installation. 
These two initial phases are the most critical since the first regrowth of the dyke is the basis from which the two subsequent phases will be generated, so the support of this dyke must be located on competent natural ground or on the pre-existing dyke. Figure 6 shows a detail of a typical section of the containment dyke that will be built using the downstream construction method.

The removal of the mine waste dump is planned on the west and southwest sides of the facility, with an estimated total volume of $\approx 964,500 \mathrm{~m}^{3}$. This sector must be removed for the extension of the containment dyke and to meet the tailings discharge capacities that will be generated during the life of the mine. The removed waste materials will be used for the construction of the dykes and also will be used to construct of the granular drainage layer, where the bottom drains are located.

In the western sector of the installation, the plan is for the dyke to rest on suitably prepared mine waste, or directly on the natural Tertiary ground. In the northeastern sector, the site investigations have confirmed the absence of the old dyke, which suggests that there has free spillage in that sector, due to the irregularity of the terrain. Two possible strategies for dealing with this problem were analysed:

1. Excavation of the old tailings located at the base of the Phase 1 foundation of the dam. In this alternative, excavation of the dyke foundation is proposed by means of sheet piling and subsequent filling with competent material from the existing dump.
2. Improving the Phase 1 foundation terrain of the dam using gravel columns.

Due to the thickness of tailings in most of the area, the second alternative was chosen.

With regard to the drainage system, two separate drainage systems were designed: an underdrainage system below the waterproofing sheet, and a bottom tailings drainage system, both connected to leakage collection pipes located downstream at the foot of the main dyke, to be connected to the water collection pool.

A sub-drainage system under the liner placed at the bottom of the dam is needed because:

- Part of the designed dyke does not sit on totally impermeable ground, but on a layer of saturated old tailings deposited at an earlier stage of the mine.

- There is natural groundwater flowing downstream of the existing clean water dam.

- Measures are needed to dissipate the pore pressures, as an additional safety measure, to improve the dyke's stability.

The facility's underdrain system has been designed to control and facilitate leakage collection. It is made up of drains composed of grooved polyethylene pipes of different diameters, depending on their arrangement in the pond, selected gravel, and a geotextile covering that will prevent fines contaminating the system.

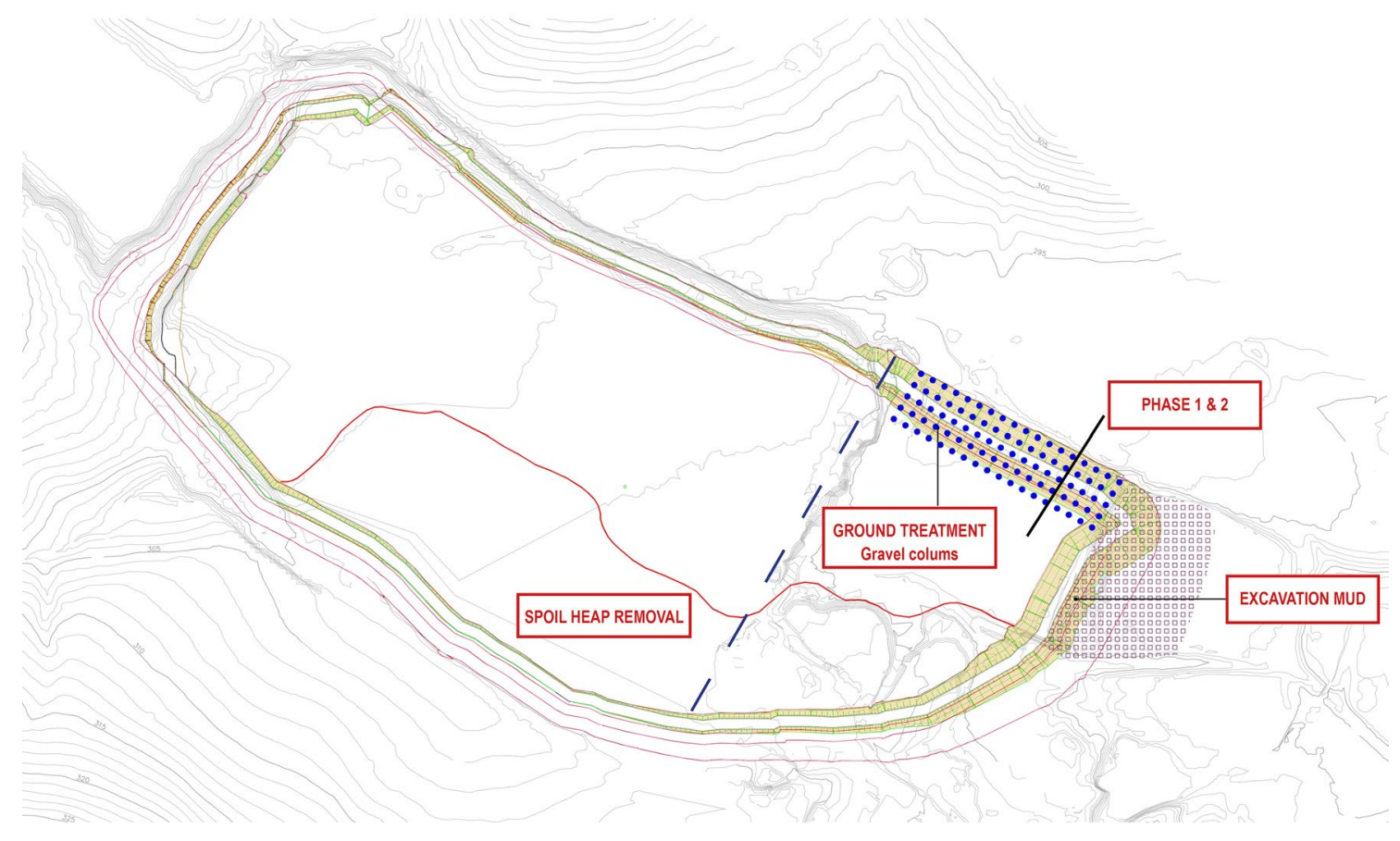

Fig. 5 General plant of the deposit, increase of the containment dikes and actions 


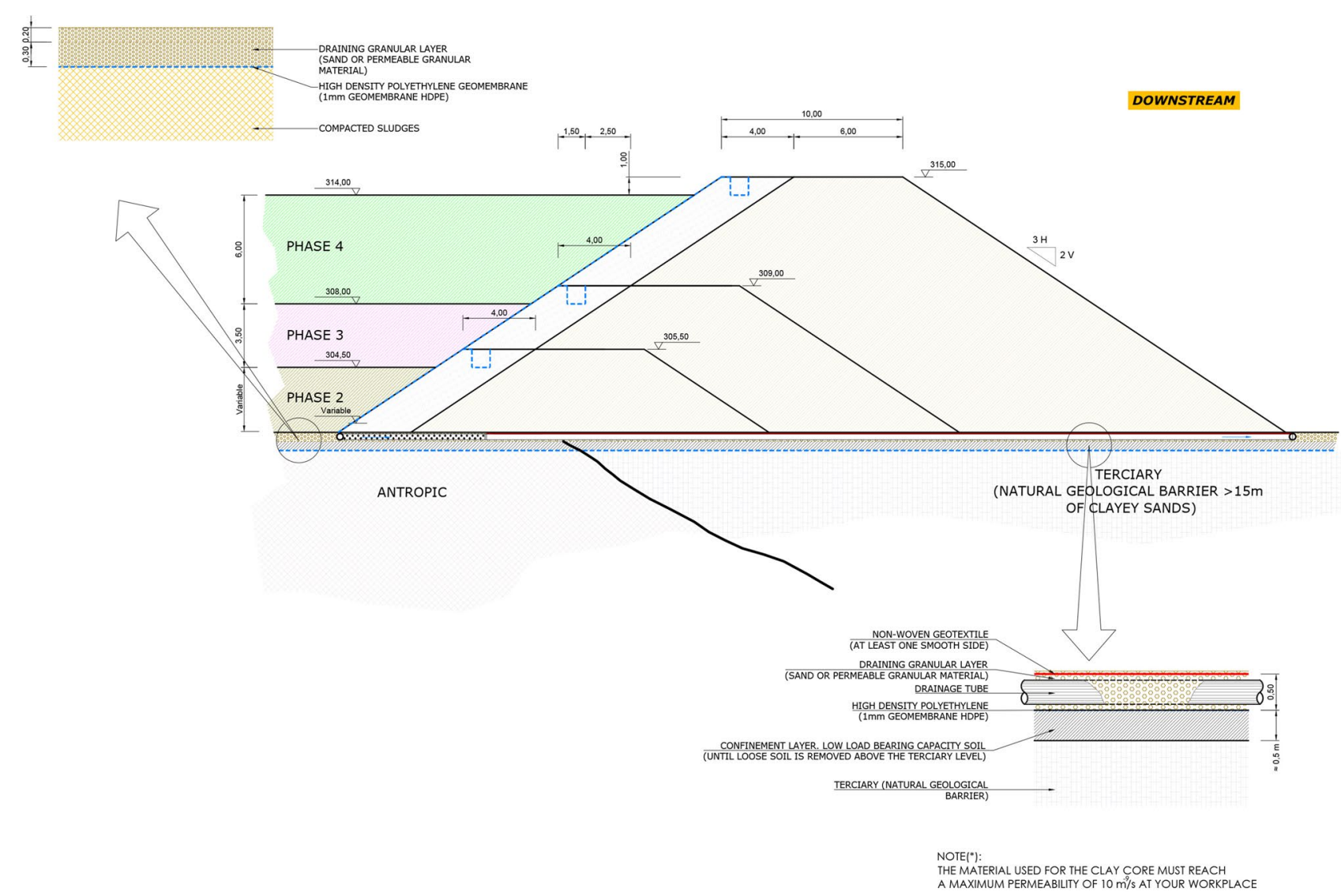

Fig. 6 Typical section of the perimeter dyke

The drains will be placed in a fishbone shaped pattern with a minimum slope of $1 \%$ and a minimum depth of $2 \mathrm{~m}$, after the excavation and cleaning of the trench. In addition, secondary drains must be installed to collect contributions from the southern slope. The drains will be connected and discharged to the seepage collection pool located in the southeast area of the dam by means of a pipe that crosses the foundation of the dam.

The exit of the sub-drainage system through the dyke is made by means of $315 \mathrm{~mm}$ polyethylene corrugated pipe, which must be extended to the foot of the final dyke to ensure sub-drainage in all future stages of dyke regrowth. The effluent collected at the outlet can be recirculated to the dam itself or disposed of in the clear water or treatment pool, depending on the quality of the water collected.

\section{Construction of the Dyke}

Design and construction of the tailings dam over the existing dam from the 1980s has greatly affected the dam's design. Figure 7 shows an aerial view of the area in which the new dam has been constructed, while Fig. 8 shows the dam after its completion. Phase 1 of the tailings facility was completed in June 2019. The construction activities can be summarized as follows:

- Foundation of the dam and preparation of the reservoir basin:

- $\quad$ removal of the old tailings from the southern area of the future dam, including replacing the foundation of the current dam (app. 964,500 $\mathrm{m}^{3}$ )

- ground improvement with gravel columns over an area of $\approx 10,000 \mathrm{~m}^{2}$, spaced 2.4 and $3.5 \mathrm{~m}$ apart

- Sub-drainage and underdrain systems

- Construction of the dyke

\section{The Dam Foundation and Preparation of the Reservoir Basin}

Three different foundation materials for the dam exist: clayey sands, inert dump material, and tailings mud. Where the foundation overlies existing tailings, two different solutions were used: excavation and substitution $(<10 \mathrm{~m}$ thick $)$ 

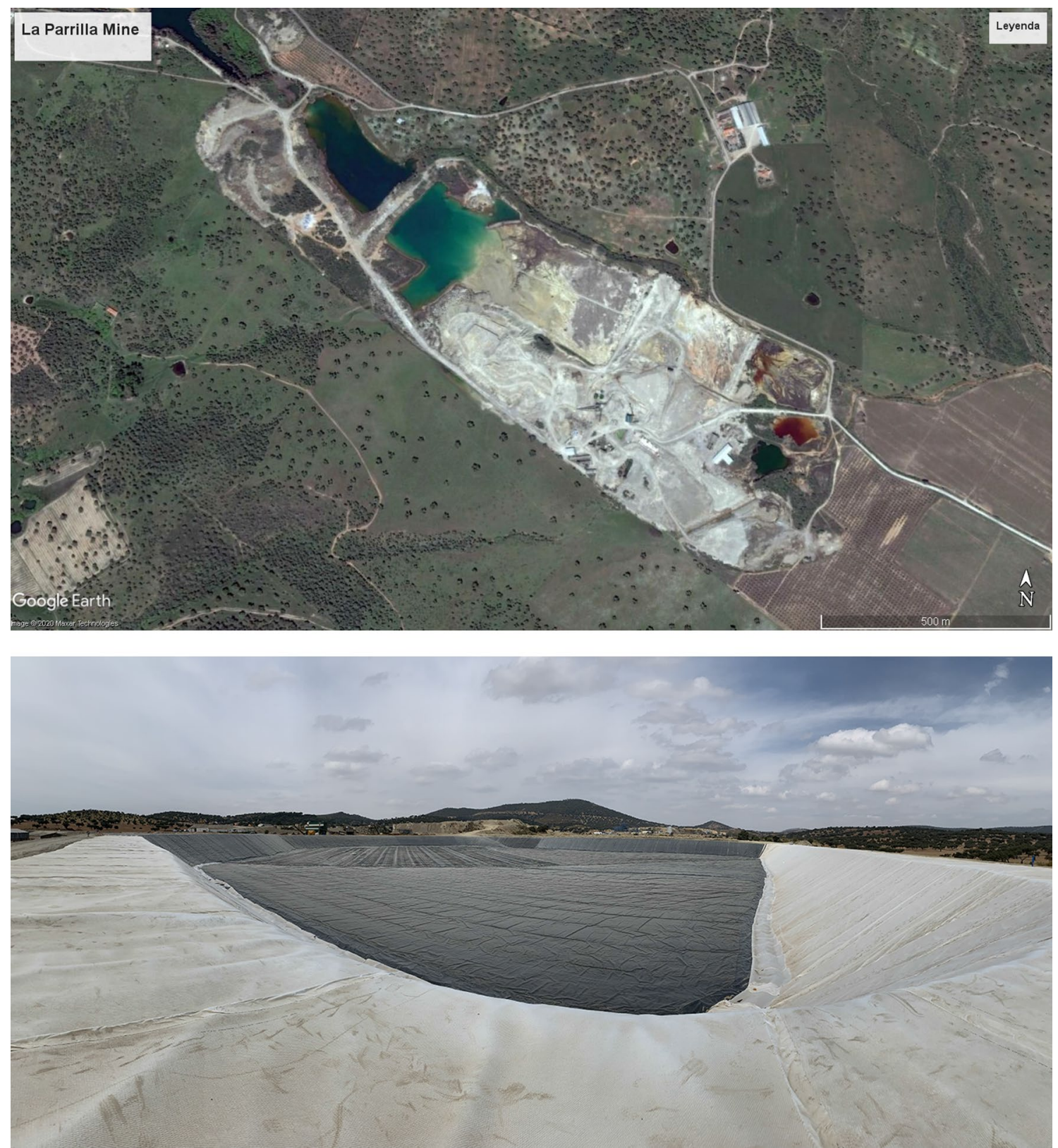

Figs. 7 and 8 Left: aerial view of the pre-existing dump and tailings facilities. Right: general view of the current tailings dam

and gravel columns. Figures 9 and 10 shows these two solutions for the dam's foundation.

The preparation of the foundation began in August 2018 and was carried out in two stages. First, the foundation of the support body of the dam was prepared in the east and southeast dikes by removing the old tailings and substituting competent rock material. Removal and substitution of the old tailings was also done in the eastern portion of the site, preparing for the future phases. In the north dikes the foundation ground was improved by creating columns of gravel, along with partial removal of the old tailings.
The area located east of the new plant tailings dam, bounded by the local road and the access road to the La Parrilla mine, consisted of an old tailings facility. These were saturated and therefore constituted a soft soil deposit with an estimated thickness of 4-6 m. For the construction of the new dyke and to ensure the stability of the structure, a soil improvement of the area was carried out, which consisted of a soil replacement in a $10 \mathrm{~m}$ wide band parallel to the dyke boundary at its final stage.

These tailings and poor soil were replaced by placing core blocks on top of the silts and compacting with an excavator and roller until no more blocks could be placed on site. 

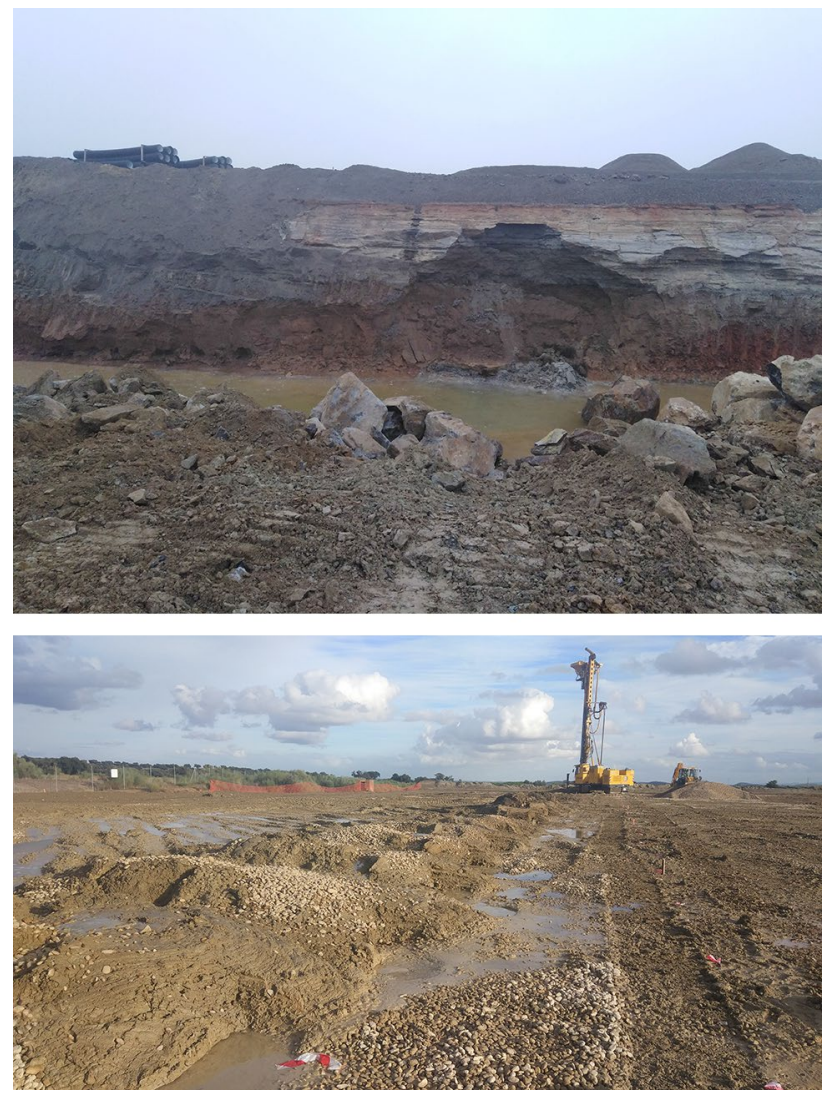

Figs. 9 and 10 Left: excavation and substitution of old tailings. Right: execution of the gravel columns

Figures 11 and 12 shows the tailings removal and replacement with coarse material.

The north dike for the new tailing's storage facility was the most critical one as it is the area in which the existing tailings thickness is systematically over $6 \mathrm{~m}$ thick. Therefore, to ensure the stability of the dyke, it was decided to improve the ground foundation using gravel columns rather than removal and substitution.

The Phase I dam is trapezoidal, with a crest width of $10 \mathrm{~m}$ at $302 \mathrm{~m}$ asl. The total height of the dam, measured from the foot upstream to the crest, is $9 \mathrm{~m}$. The outer slope has an inclination of $3 \mathrm{H}: 2 \mathrm{~V}$, while the internal slope has an inclination of $3 \mathrm{H}: 2 \mathrm{~V}$.

\section{Sub-drainage and Underdrain Systems}

Subsequently, the sub-drainage system already described was installed. Figures 13 and 14 show the installation of the main pipe of the sub-drainage system. Once the subdrainage system was constructed and the reservoir basin was prepared, the next step was extension of the waterproof liner. The waterproofing method used in the facility consists of
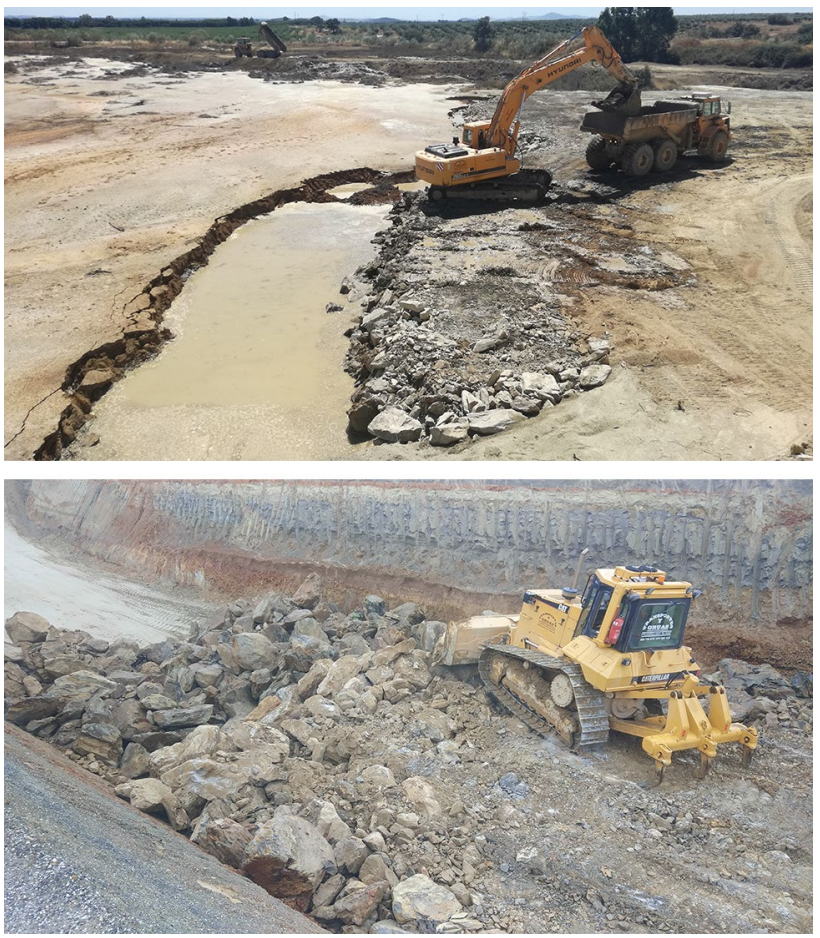

Figs. 11 and 12 Tailings removal and replacement with coarse selected material

successive layers of geosynthetic materials and compacted materials, depending on their position in the basin. Figures 15 and 16 show the installation of the drainage system at the bottom of the basin.

The main activities for the installation of the waterproofing system consisted of the following:

- Preparation, re-profiling, and compacting the foundation.

- Laying of the geotextile and/or bentonite geo-composite.

- Paving and welding of the geomembrane.

- Repairing defects and non-conformities.

- Extension and installation of geo-drainage compound on the north and east slopes.

To affix the membrane to the surface and limit and control its movement, two types of anchorages were installed: a perimeter trench around the entire facility in which the geosynthetic materials were placed and cords made of synthetic laminate as a filled pipe that allowed the additional fastening of the geo-drainage compound to the waterproofing sheet. In addition, the drainage system on the sheet on the northern and southeastern slopes, by means of gravel filling, provided an additional anchorage in these areas for the system. Figures 17 and 18 show the processes of waterproofing and dam cutting. Finally, the bottom drainpipes were installed. 

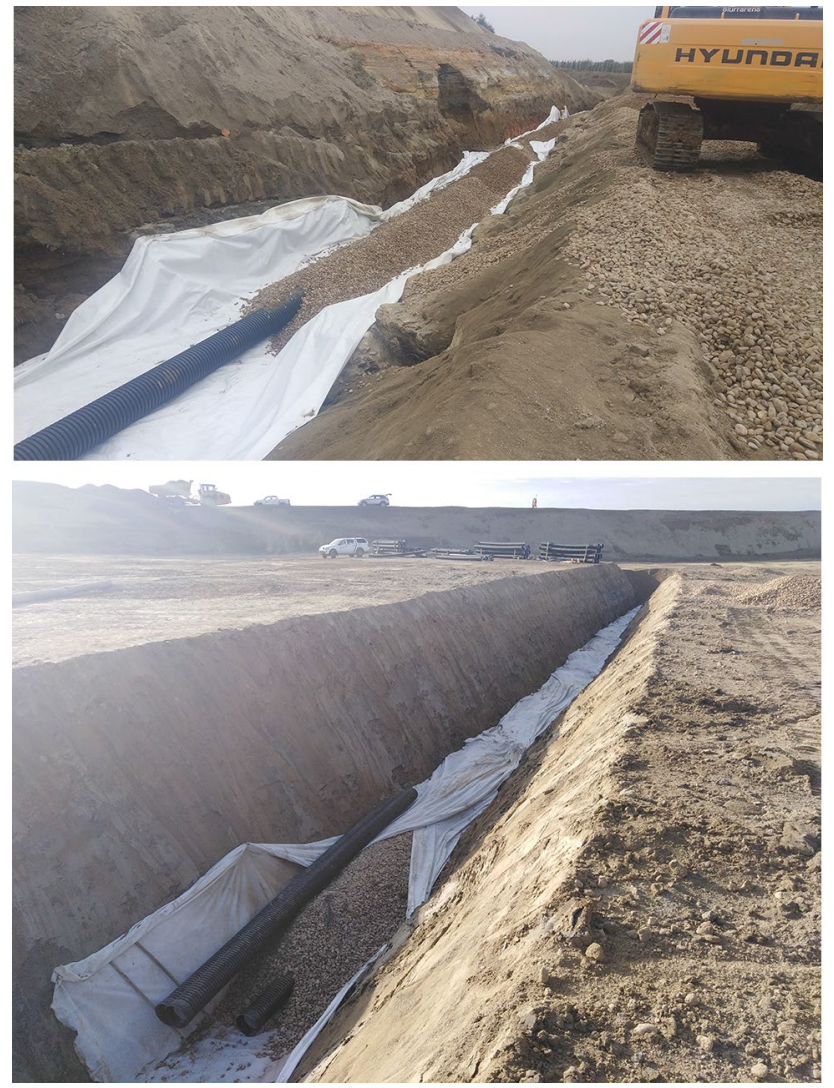

Figs. 13 and 14 Installation of the sub-drainage system

\section{Construction of the Dyke}

The dam has mostly been built from plant reject materials from the treatment of the old waste dumps (all with a granulometry greater than $3 \mathrm{~mm}$ ) and rocky mine tailings. All the materials come from the mining facilities themselves, stored in old dumps. Figures 19 and 20 show the construction process of the basin bottom.

\section{Monitoring Plan}

The monitoring plan is based on a predictive model, based on the results of the stability calculations performed, in which the increased pore pressure in the foundation ground, expressed as a Skempton Bbar value (Skempton 1954) at the foundation, the piezometric level at the dam, and the
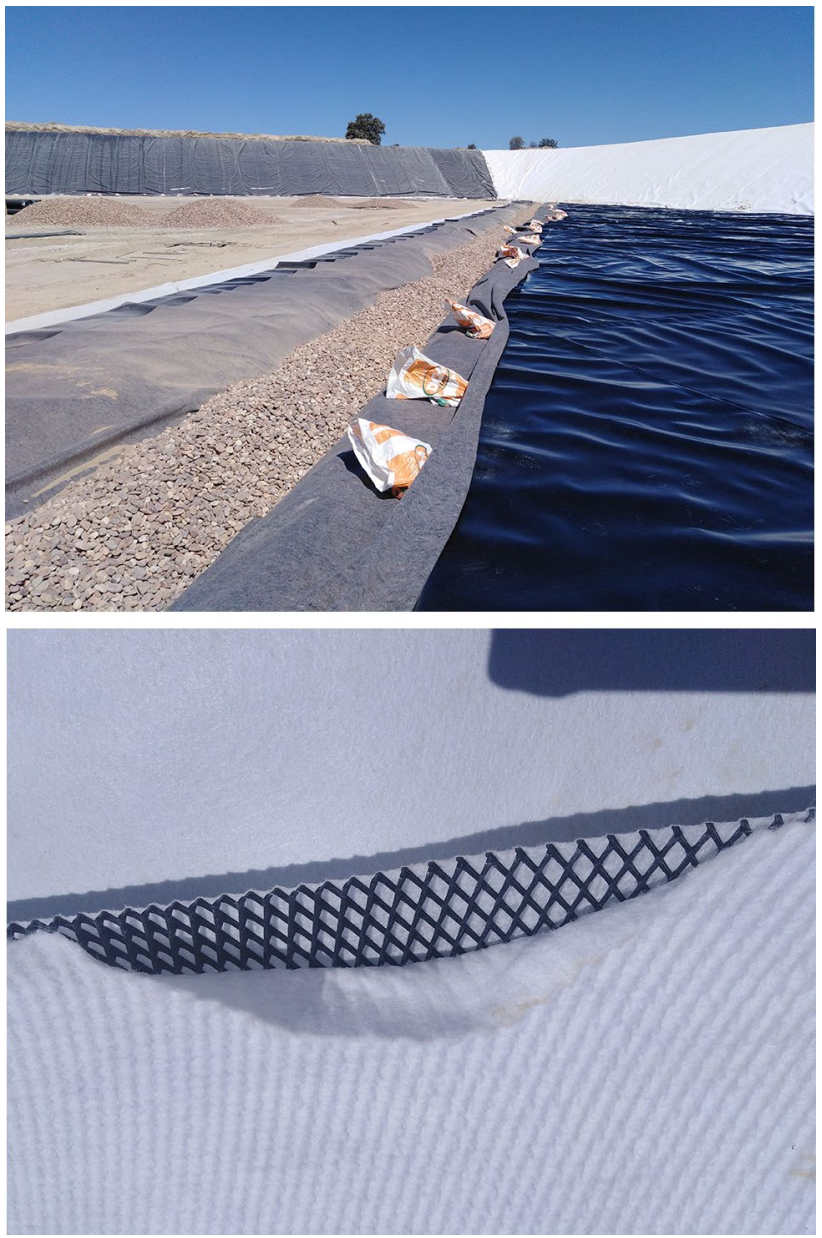

Figs. 15 and 16 Left: drainage on a sheet at the bottom of the pond. Right: geo-drain composite detail

displacements at the foundation and the dam were foreseen as three different values: precaution, alert, and alarm.

To control the displacements and the evolution of the pore pressures, an instrumentation plan was defined. Figure 21 shows the instrumentation that has already been installed:

- Open and wire-vibrating piezometers.

- Total pressure cells.

- Topographical prisms.

- Inclinometers. 
Figs. 17 and 18 Left: Waterproofing system installation. Right: east dike cutting
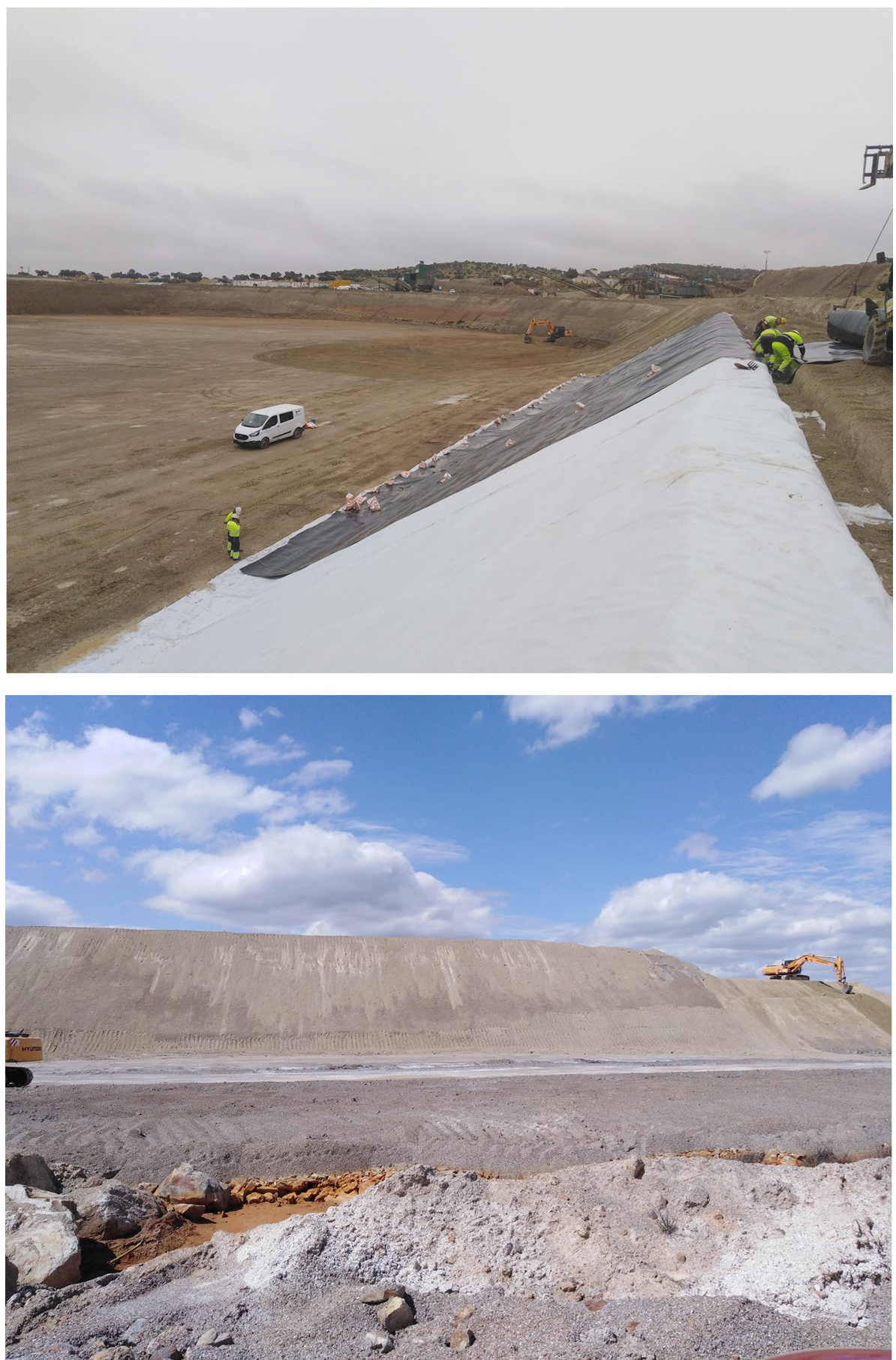

\section{Conclusions}

La Parrilla is a tungsten and tin mine located in the Extremadura region of western Spain. The design and construction of the new tailings facility at this mine has been a great challenge because part of it is located over an existing tailings facility from the 1980s, in which three different foundation materials for the dam exist: clayey sands, inert dump material, and tailings mud. The construction of a containment dyke over an imprecisely characterised ancient tailings facility represents a major challenge in its design. 
Figs. 19 and 20 Left: Pouring, spreading and compacting of material at the bottom of the pond. Right: end of raft bottom
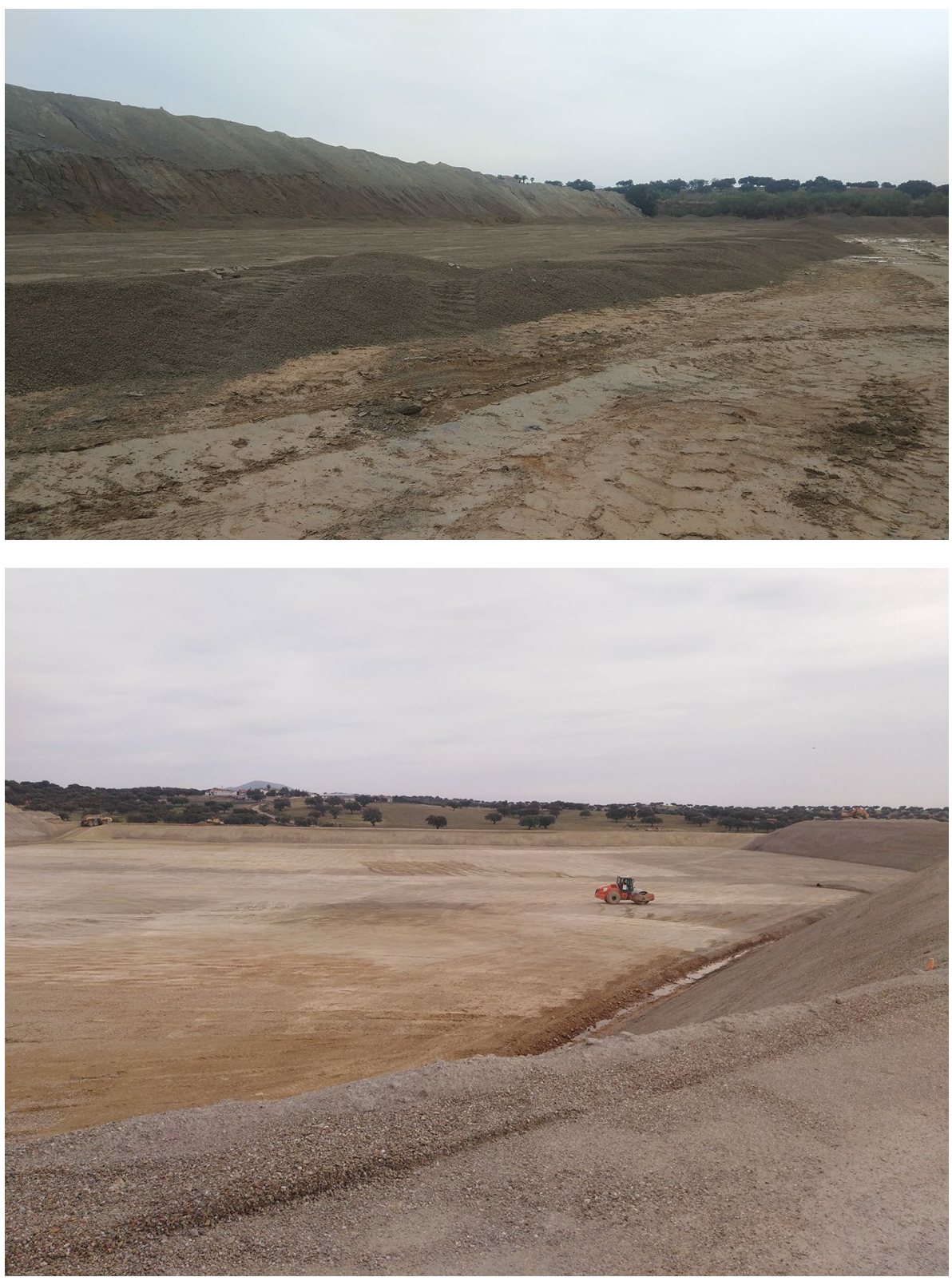


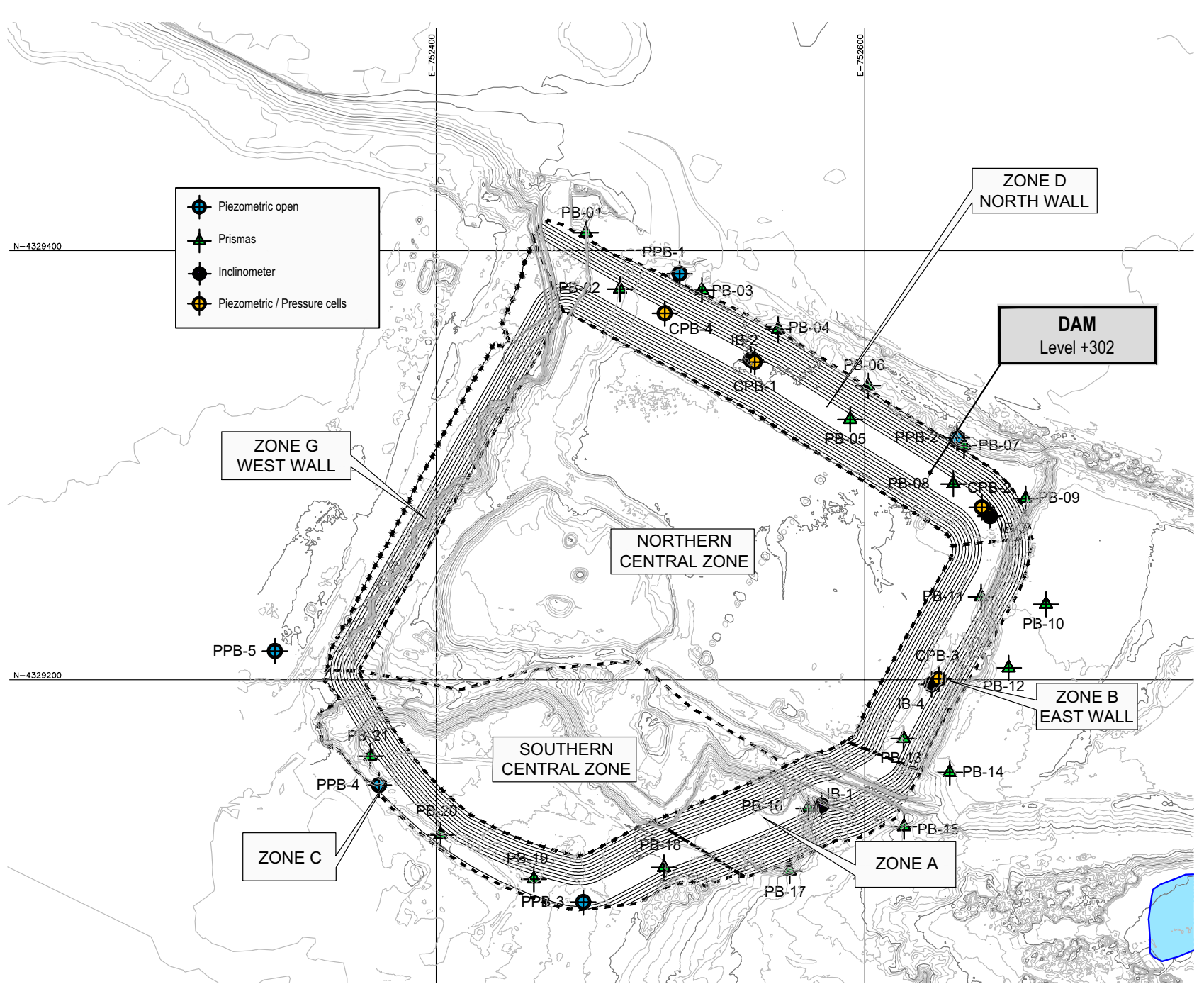

Fig. 21 Installed instrumentation for the La Parrilla tailings pond

Phase 1 was constructed from August 2018 to June 2019 considering these constraints, and all of the monitoring sensors have already been installed, so the facility is completely prepared to receive tailings from the new plant. The improvement of the foundation ground of the new dam, by means of columns of gravel where the thickness exceeds $10 \mathrm{~m}$, has proven to be a very effective way to guarantee the stability of the dyke.

Open Access This article is licensed under a Creative Commons Attribution 4.0 International License, which permits use, sharing, adaptation, distribution and reproduction in any medium or format, as long as you give appropriate credit to the original author(s) and the source, provide a link to the Creative Commons licence, and indicate if changes were made. The images or other third party material in this article are included in the article's Creative Commons licence, unless indicated otherwise in a credit line to the material. If material is not included in the article's Creative Commons licence and your intended use is not permitted by statutory regulation or exceeds the permitted use, you will need to obtain permission directly from the copyright holder. To view a copy of this licence, visit http://creativecommons.org/licenses/by/4.0/.

\section{References}

Campos R, Sanderson DJ, Gumiel P, Roberts S (1995) Geometría y fractalidad de los sistemas filonianos de la mina de La Parrilla (Cáceres): Conectividad y percolación. Bol Geol Miner 106(4):16-37 ((in Spanish))

Gumiel P, Campos R (2002) La Banda de Cizalla de Montánchez y su influencia en las mineralizaciones filonianas de Sn-W (Mina de La Parrilla). Publ. Esp. AGEX (ISBN.84-699-9634-7) (in Spanish)

Skempton AW (1954) The pore-pressure coefficient A and B. Geotechnique 4:143-147 